\title{
Orthodox Education in Poland
}

\author{
Antoni Mironowicz \\ Uniwersytet w Białymstoku \\ Polska \\ amir@uwb.edu.pl
}

Antoni Mironowicz, Edukacja prawosławna w Polsce, Elpis, 18 2016: 27-35.

\begin{abstract}
The Orthodox educational system has been meeting important tasks, which is raising a general mental level of clergy and faithful. Its foundation was driven by needs of the Orthodox Church. Educating a young generation in the spirit of the Orthodoxy happened to be the main task of the enlightened class. Brotherhood, monastery and parish school were to be part of this program. The Orthodox education shaped religious life, helped preserve the religious and national identity of the believers. An evidence of that is the fact, that only those localities preserved "the Greek faith ", in which next to the monasteries were schools. Higher education, and especially Mohyla Academy, shaped by the then elite, played a vital role in the history of Orthodox Church in the Republic and neighboring countries. A similar role had to play in the interwar period College of Orthodox Theology at the University of Warsaw and in post-war Orthodox Section of the Christian Academy of Theology

Presented here outline of history of Orthodox education in Poland indicates to the, appreciated by clergy and hierarchy, need of development of theological schools. Theological schools played and still play important role in shaping the attitudes of clergy and faithful. Schools provide necessary pastoral resources, shape Orthodox cultural and scientific environment. Theological education has remained an essential element for the proper functioning of Orthodox Church in the Polish Republic.
\end{abstract}

\begin{abstract}
Streszczenie: Prawosławny system oświatowy spełniał ważne zadania w podniesieniu ogólnego poziomu umysłowego społeczności ruskiej. Jego powstanie wynikało z potrzeb Cerkwi. Wychowanie młodego pokolenia w duchu prawosławnym stało się głównym zadaniem warstw oświeconych. Szkoły brackie, przyklasztorne i przycerkiewne miały być elementem tego programu. Szkolnictwo prawosławne kształtowało życie religijne, pozwoliło zachować tożsamość wyznaniową i narodową wiernych. 0 jego znaczeniu świadczy fakt, że jedynie te miejscowości zachowały „,wiarę grecką”, w których obok monasterów istniały szkoły. Szkolnictwo wyższe, a zwłaszcza Akademia Mohylańska, formowało ówczesne elity, które odegrały istotną rolę w dziejach Kościoła prawosławnego w Rzeczypospolitej i w krajach sąsiednich.

Przedstawiony rys dziejów szkolnictwa prawosławnego w Rzeczypospolitej wskazuje na docenianie przez hierarchię i duchowieństwo potrzeby rozwoju szkół teologicznych. Uświadomienie konieczności dobrego przygotowania kadr w odległej i mniej odległej przeszłości potwierdza, wysoki stan świadomości religijnej elit prawosławnych. Szkoły teologiczne odgrywały i odgrywają ważną rolę w kształtowaniu postaw duchowieństwa i wiernych. Szkoły dostarczają niezbędnej kadry duszpasterskiej, kształtują prawosławne środowiska kulturalne i naukowe. Szkolnictwo teologiczne zawsze było i pozostaje niezbędnym elementem do prawidłowego funkcjonowania Kościoła prawosławnego w Rzeczypospolitej.
\end{abstract}

Keywords: Orthodox Church, Education, Poland

Słowa kluczowe: Kościół prawosławny, Edukacja, Polska

The state of knowledge about Orthodox education in the Polish-Lithuanian Commonwealth reflects the state of research in the history of the Eastern Church in general. Few papers on Orthodox education come mostly from the last century. Activity of Orthodox schools was described by K. Xarlampović, S. Miropolsky, E. Medynsky, A. Savich, I. Krypjakevych, I. Pavlovsky, A. Wańczura'. Education on

\footnotetext{
K. Xarlampović, Zapadno-russkie pravoslavnye shkoly XVI i nachala XVII w., Kazan 1898; Idem, Ostrozhskaia prawoslavnaia shkola, „Kievskaia Starina" 1897, Vol. 2; J. Pavlovsky, Prikhodskie shkoly v staroi Malorussii i prichiny ich unichtozhenia, Kiev 1904; A. Savich, Zapadno-russkie uniatskie shkoly XVI-XVII w., Trudy Bieloruskogo Gosudarstviennogo Univiersitieta w Minskie", Minsk 1922, No. 2-3; A. Wańczura, Szkolnictwo w Starej Rusi, Lwów 1932; I. P. Krypjakevych, Z istorii halytskoho shkilnytstva XVI-XIII st., ,Ridna szkoła", Lwiw 1933, No. 2; E. N. Medynsky, Bratskie shkoly Ukrainy i Bielorussii w XVI-XVII w., Moscow 1954; S. Miropolsky, Ocherk istorii tserkovno-prikhodskoi shkoly od piervogo ieia vozniknienia na Rusi do nastoiashchego vriemieni, 3rd ed., Sankt-Peterburg 1985; A. Mironowicz, Szkolnictwo prawosławne na ziemiach białoruskich $w$ XVI-XVIII wieku, "Białoruskie Zeszyty Historyczne", No. 2, Białystok 1994, pp. 20-34; Iden, Prawosławne szkolnictwo teologiczne na terenie Rzeczypospolitej,
}

Ruthenian lands was studied mainly in the context of the activities of Orthodox brotherhoods. Work of I. Flerov, A. Papkov and I. Isaievych ${ }^{2}$ shall be regarded as fundamental. The issue of Orthodox education was undertaken on the occasion of the monographs of individual religious centers or people associated with them ${ }^{3}$.

„Wiadomości PAKP”, No. 7-8 (140-141), Warsaw 2001, pp. 13-19; Idem, Kościót prawosławny w dziejach dawnej Rzeczypospolitej, Białystok 2001

2 I. 0. Flerov, 0 pravoslavnykh tserkovnych bratstvach protivoborstvovawshikh unii w Jugo-Zapadnoi Rossii v XVI, XVII, XVIII st., Sankt-Peterburg 1857, A. A. Papkov, Bratstva. Ocherk istorii zapadno-russkikh pravoslavnykh bratstv, Sankt-Peterburg 1900; W. A. Shokolo, Do pitannia pro istoriu bratstv $i$ ich shkil na Ukraini w kinci XVI na pochatku XVII st., „Navukovi Zapisky Donetskoho pedinstituta”, vyp. IV, Donieck 1956; I. D. Isaievych, Rol bratstv w izdanii i rasprostranenii knig na Ukrainie i Bielorussii, „Kniga i grafika”, Moscow 1972; tenże, Bratstva ta ikh rol w rozvytku ukraińskoi kultury XVI-XVII st., Kiev 1966; I. Kamanin, Jeshcho o drievnosti bratstva $i$ shkoly $w$ Kievie, „Chtienia w istoricheskom obshchestvie Nestora Letopistsa", t. 11. Kiev 1985.

3 M. Vozniak, Pysmenyc'ka dijal'nist' Ivana Borec'koho na Volyni i u Lvovi, Lwiw 1954; F. J. Naumienko, Pedahoh humanist i prosvititiel Iov Borec'ky, 
History of Orthodox education in the Ruthenian lands dates back to the $11^{\text {th }}$ century. There were schools at the courts of grand dukes and episcopal cathedrals, but only small percentage of the then social elite was in their range. The school of copiers and writing icons at Transfiguration (of the Savior) Monastery in Polotsk founded by St. Euphrosyne (1110-1173) is mentioned by authors of her hagiography. In Turov, schools were at episcopal cathedral and monasteries in the period when the local ordinary of the diocese was St. Cyril of Turov (1169-1182). Schools were established to satisfy Orthodox Church's needs and were the effect of evolution of religious and cultural life in the Polotsk and Turov lands in the $12^{\text {th }}$ and $13^{\text {th }}$ century. Key role in this process played Saint Bishops of Polotsk: Mina (1105-1116), Dionysius (1166-1187) and Simon (12661289); and Bishops of Turov: Cyril and Lavrentij (11821194). Equally great merit in the development of education had the dukes of Kiev: Yaroslav I the Wise and Vladimir II Monomakh.

The development of the parish and monastery schools started only at the end of $15^{\text {th }}$ and in $16^{\text {th }}$ century, together with the overall development in education in the Grand Duchy of Lithuania. At that time education under the auspices of townspeople and Orthodox brotherhoods came into view. The development of education was non-accidental phenomenon, because it matched with period of religious controversy and the battle for the preservation of established dogmas of each faith. Education, according to the then Orthodox Church hierarchy, was to play an important role in preserving the religious identity of the faithful. Defense of their own faith, liturgy, and Church Slavonic language could be achieved only through own education. Important role in the development of Orthodox education had the provisions of Council of Brest of June 26, 1594, saying that annual synod of bishops and clergy people "in the writing of God educated" were considering, in addition to church's issues, also issues of science and education ${ }^{4}$. At the same synod, Bishops pledged to set up brotherhood's schools, printing-houses and hospitals in their dioceses. In accordance with the provisions of the Council, in every city should be school, and metropolitans, bishops and archimandrites annually should cast $1 / 10$ of its revenue at their maintenance ${ }^{5}$. Several months later, Duke Constantine Ostrogsky reproached bishops with "provisions of councils in the matter schools, printing-houses and other key elements for the Orthodox Church, which are completely ignored"6. Vladikas were against putting schools into the hands of lay people, therefore, on August 2, 1595, obtained from Sigismund III Vasa privilege, in which the king extended their authority over the brotherhoods and gave them exclusive

Lviv 1963; Z. J. Chizniak, Kievo-Mohilanskaja Akademia, Kiev 1981.

4 Akty otnosiashchiesia $k$ istorii Zapadnoi Rossii, (further reffered as: AZR), Vol. 4, Sankt-Peterburg 1853, No. 25.

5 Ibid., Vol. 4, No. 48, ref. 4, 5 .

6 Ibid., Vol. 4, No 63; A. Mironowicz, Szkolnictwo prawosławne..., p. 22. right to "set up schools and seminars of Greek and Slavic language".

$*$

Orthodox education in $16^{\text {th }}-18^{\text {th }}$ centuries can be categorized into monastery schools, parish schools and brotherhood's schools. A separate category in the Commonwealth was the centers of higher education - Ostroh Academy and Kiev-Mohyla Academy.

Monastery schools were the most stable. In their range of action was a small number of young people, in practice, from a few to a dozen students and education conducted was at the elementary level. In monastery schools, in addition to teaching of reading and singing, Church Slavonic, Ruthenian, sometimes also Greek and Polish languages were taught. The scope of knowledge was limited by monk's teaching skills. Such schools operated in the urban monastery centers, which had strong demand for educated staff. Large centers of monastic life situated away from the cities did not have any schools.

Parish schools were organized to train two or three pupils in the subject of services order, reading and writing and basic principles of faith. The level of these schools depended on education and capacity of cleric. In elementary schools, students were divided into three groups: the first studied how to put letters together, the other - to read by rote, the third - to speak out, judge and reason. On Sundays, teacher explained to students the text of the Gospel and the Acts of the Apostles from liturgy read on that day. The teacher had the right to reprimand parents for lack of care and concern for children8. Juveniles of parish schools were clerics or kept auxiliary functions in the church.

$*$

Institutions carried out by Orthodox brotherhoods were of the greatest importance for the development of Orthodox education in the former Poland. The emergence of brotherhood schools in the monasteries and parishes was dictated not only by the needs of Orthodox Church, but also by the necessity of educating the young generation in the spirit of Orthodoxy. Therefore, it is not surprising that in the second half of the $16^{\text {th }}$ century the nature and role of those schools completely changed. Brotherhood schools performed role of the secondary education. Their level, however, depended on the financial situation of particular brotherhood and possibility of obtaining adequate teaching staff. The first brotherhood school was established in 1584 in Vilnius. Stefan Batory granted the privilege to the brotherhood to establish schools, which would teach Ruthenian, Greek, Latin and Polish languages?. Soon two elementary schools arose in Vilnius and the first on those lands Orthodox gymnasium with humanist profile. Vilnius schools had become a model for other brotherhood schools. The

\footnotetext{
AZR, Vol. 4, No. 79.

8 Ibid., pp. 111-113.

9 Ibid., Vol. 3, No 144. Another brotherhood school was working in Lviv. In 1586 r. brotherhood was granted a special privilege by Patriarch Joachim of Antioch. See K. Xarlampović, Zapadno-russkie..., pp. 287-311.
} 
privilege of Stefan Batory attributed to Vilnius brotherhood in 1585 has been extended to all members of the Orthodox Church. Then it was allowed to build hospitals and schools "of wood, and also of stone"10. Above mentioned Vilnius schools run by the brotherhood and monastery of St. Trinity and Holy Spirit were of particular importance in shaping Orthodox elites ${ }^{11}$. In Vilnius brotherhood school lecturers were among others: Stefan Zyzani, Cyril Lukarys, Ivan Borec'kyj, Meletij Smotryc'kyj and Teofil Leontowicz. School raised many prominent religious and cultural activists (Anastazy Brzesky, Sylvester Kossov, Józef Nielubovich Tukalsky, Teodozy Wasilewicz) ${ }^{12}$. Its graduates became lecturers in other brotherhood schools in the Polish-Lithuanian Commonwealth.

Brotherhood school in Lviv performed similar role. Thanks to the privilege of Patriarch Jeremiah II of 1589, lifting Lviv brotherhood of the Dormition to the rank of the stauropegial (stauropegic), the matters of education were also regulated. The privilege enabled brotherhood to create schools for children of its members and ordered maintaining only "blahochestivykh" clergy for teaching Slav and Greek language ${ }^{13}$. In this school, emphasis was placed on the Slavonic and Greek. The main organizer of this school was Greek, Metropolitan Arsenius of Elasona. The school had the task of providing knowledge for "the Christian children, in order not to lose their faith, by drinking from other sources water of pagan sciences, thus pervading destruction closely proceeds"14 In Lviv, Latin language was not taught and the use of "vulgar speech" was forbidden.

An important role in the history of Orthodox education has been played by Brest school. Its founders were Brest townspeople, who on July 6,1590, acquired the privilege of Meletij Chreptovich, Vladimir-Brest Bishop (15881593). It appears from the document, that Brest townspeople were "ktitors of cathedral" and wanted to have own school with one or two teachers. This school was to serve not only townspeople, but also to all those who wanted to be educated there ${ }^{15}$. From the royal privilege of January 28, 1591, appears that townspeople built school on municipal land opposite to the church of St. Nicholas and asked the king to release school building and lands belonging to school from all tax obligations. Sigismund III Vasa acceded to the requests of Brest townspeople ${ }^{16}$. Thanks to the efforts of the then Brest castellan, Adam Potija (later Bishop Ipatij), Orthodox brotherhood, which took care of the functioning of this school, was established. In 1592 one of the

\footnotetext{
10 Ibid., p. 281.

11 Ibid., pp. 311-331; I. 0. Flerov, O pravoslavnykh..., pp. 94-96.

A. Mironowicz, Teodozy Wasilewicz, archimandryta stucki, biskup białoruski, Białystok 1997; Idem, Metropolita Józef Nielubowicz Tukalski, Białystok 1998; Idem, Sylwester Kossow, władyka białoruski, metropolita kijowski, Białystok 1999.

13 I. 0. Flero, O pravoslavnykh..., p. 108.

14 K. Xarlampović, Zapadno-russkije..., pp. 287-296.

15 Arkheograficheski sbornik dokumentov otnosiashchikhsia $k$ istorii Sievierno-Zapadnoj Rusi, Vilnius 1890, Vol. 11, p. 6.

16 AZR, Vol. 4, No. 28.
}

teachers of Brest school was a lecturer of Lviv brotherhood school Lavrentij Zyzani, a well-known author of polemics ${ }^{17}$.

At school, in addition to the course in the church services and chant, several languages have been taught: Church Slavonic, Ruthenian, Greek, Polish and Latin. At the end of the 16th century Brest school matched Lviv and Vilnius schools with its level. Bringing good teachers has been possible thanks to the rich donations for the school from the Potij family ${ }^{18}$. After the death of Meletij Chreptovich in 1593, Ipatij Potij became Vladimr Bishop (1593-1613) and tried to submit school and brotherhood to his authority. In this situation some teachers had to abandon Brest and go to Vilnius. Ipatij Potij wrote about them to Prince Constantine Ostrogsky on March 25, 1595' ${ }^{19}$. Brotherhood and the school, which defended the canons of Orthodox Church, have been named by Ipatij Potij "heretics excommunicated from the Church of God". Bishop Potij, after adoption the union on October 3, 1596, forbade clergy maintaining any contacts with the school ${ }^{20}$ and took actions aiming to overtake school from the brotherhood. Utilizing royal support, Uniat Bishop achieved that goal on June 26, $1597^{21}$. School ceased to function independently and has become a tool in the hands of Ipatij Potij, used to promote the union. Whereas brotherhood gathered around the Church of Nativity BVM, at which school for members of the Orthodox Church was founded in 1641. After taking over the school by Uniats at the end of the 17th century, Orthodox attended the monastery schools. They were working in the 18th century at the Brest monasteries of St. Simeon and the Birth of Christ the Savior. Monastery schools were the only educational centers for the Orthodox residents of Brest.

Kiev school was founded in 1588 at brotherhood monastery. Destroyed by fire in 1614, was rebuilt year later by the donations of Anna Hugulewiczówna. In 1620 the Patriarch Teofanes of Jerusalem granted the brotherhood school special privilege, in which stressed the need for education of young generations, and especially learning about the dogma of faith. After taking the dignity of Archimandrite of Kiev Pechersk Lavra by Petr Mohyla, began the process of introducing Polish and Latin languages to the Ruthenian education ${ }^{22}$.

Lutsk brotherhood had school already in 1617. In 1624 brotherhood has developed the rule, which discribed precepts for school operation. In the Lutsk brotherhood school were lectured: Greek and Slavic language, grammar, the order of church services (act), rhetoric and dialectics. Orthodox school in Lutsk survived until the beginning of the 18 th century ${ }^{23}$.

Significant role in development of the Orthodox education played Mogilev brotherhood school at the Church of

\footnotetext{
Ibid., Vol. 4, No. 33.

18 Ibid., Vol. 4, No. 63.

19 Ibid., Vol. 4, No. 3.

20 Arkhiv Jugo-Zapadnoi Rossii izdavaiemy Vremennoiu Komissieiu dla razbora drevnikh aktov, part. I, t. 1, Kiev 1883, No. 220; AZR, Vol. 4, p. 215.

21 K. Xarlampović, Zapadno-russkije..., p. 335.

22 I. 0. Flerov, O pravoslavnykh..., pp. 99-102.

23 Ibid., pp. 103-104.
} 
Transfiguration (of the Savior). The privilege for the foundation of it, Mogilev townspeople received from Stefan Batory on January $28,1578^{24}$. A year later brotherhood received a privilege from the Patriarch Jeremiah II of Constantinople, in which he allowed to operate the school by members of brotherhood. Sigismund III in the privilege conferred to brotherhood on March 21, 159725. After the Synod of Brest, patriarchal protosyncellus Nicefor, acknowledging the importance of the school, conditioned for the brotherhood institution not to accept Uniats neither their supporters ${ }^{26}$. About the role of school in shaping religious awareness of the Orthodox communities testifies the fact, that the then Uniat Bishop Gedeon Brolnicky (1601-1618) in 1601 accused it of bringing up young rebels and inhibiting youth from the church's union ${ }^{27}$.

Its activities in the city were stopped in 1619, when King Sigismund III Vasa subordinated institutions of the brotherhoods to the Uniat Archbishop of Polotsk Josafat Kuncevyć (1618-1623) ${ }^{28}$. After the assassination of Josafat Kuncevyć, chancellor of the Grand Duchy of Lithuania Lew Sapieha (1588-1623) ordered in 1624 the subjection of the brotherhood to Uniat monastery of Transfiguration (of the Savior). Mahilyow brotherhood school had the extended curriculum. Grammar, rhetoric, dialectic, arithmetic, geometry, astronomy and music were taught there ${ }^{29}$. In addition to that school, there were working in the city several elementary schools, in which education was limited to teaching Church Slavonic, Ruthenian and Polish languages. These schools put special emphasis on understanding the Bible and the liturgy.

An important center for Orthodox elementary and secondary education was Minsk. Existing there hospital brotherhood received on September 11, 1592, a royal privilege to establish schools with the object of "teaching small children, keeping bachelor and educating in Greek and Ruthenian scrip"30. This school, still mentioned in records in 1601 , ceased to exist as Orthodox in $1612^{31}$. In 1613 , on the place of the brotherhood at the Cathedral, new brotherhood of Sts. Peter and Paul was founded, which worked at the monastery of the same name. Brotherhood had school "to multiply the glory of God and train children"32. In 1614 the Minsk brotherhood adopted the rule of the Vilnius brotherhood, which affected the extension of the curriculum with Greek and Latin. Uniats and voivode of Minsk Petr Tyszkiewicz tried to subordinate Orthodox school to their jurisdiction. Despite these attempts Orthodox school

\footnotetext{
24 Ibid., p. 97; F. Zhubro, Istoria Mogilevskogo Bogoiavlenskogo bratstva, „Mogilevskie Jeparkhialnye Vedomosti”, 1889, p. 85.

${ }_{25}$ AZR, Vol. 4, No. 119.

26 „Mogilevskie Jeparkhialnye Vedomosti”, Mohylev 1845, No 41.

27 ASD, Vol. 2, No. 22.

28 Tsentralny Gosudarstveny Istoricheski Arkhiv Rossii, Sankt-Petirburg, Arkhiv Greko-Uniatskikh mitropolitov, Vol. 823, part 1, No 430, section 1.

${ }_{29}$ M. B. Topolska, Czytelnik i książka $w$ Wielkim Księstwie Litewskim $w$ dobie Renesansu i Baroku, Wrocław 1984, p. 63.

30 AZR, Vol.. 4, No. 36.

31 K. Xarlampović, Zapadno-russkie... p. 335.

32 Akty izdavaiemye Vilenskoiu Arkheograficheskoiu Komissieiu dla razbora drevnikh aktov $v$ Vilnie, Vilnius 1875, Vol. 11, No. 36.
}

continued to operate in Minsk under the control of brotherhood and ihumen of monastery and on March 18, 1633, brotherhood received a royal privilege confirming its exclusive right to school and printing-house ${ }^{33}$. Orthodox schools in the city survived until the fall of the Polish-Lithuanian Commonwealth. Their activity in the 18th century was supported by the Monastery of Sts. Peter and Paul and St. Nicholas Church ${ }^{34}$.

Apart from schools mentioned above there were other noted Orthodox schools with wider than elementary teaching profile in Vinnytsia (Vinnica), Lublin, Bielsko, Pinsk at the church the Holy Theophany, (early 17 th century), at the Tsepersky monastery in the Novodrod District (1618), in Vievis near Vilnius (1619), in Škłoŭ (Shklov), in Ashmyany District (1625), at Barkulabovsky Monastery (1626), in Bujnice (1633), at Kutsieina Monastery in Orsha District (1630) and Polotsk $(1633)^{35}$.

In brotherhood schools' main emphasis was put on teaching languages. Greek, Church Slavonic, Ruthenian (Old Belarusian), Latin and Polish languages were taught. Knowledge of these languages was essential for understanding sciences lectured at school. Lay subjects were grammar, poetry, rhetoric, and the dialectic philosophy. The privilege of Sigismund III Vasa of October 13, 1592, for the Lviv brotherhood school moreover lists logic, arithmetic, music, geography and astronomy ${ }^{36}$. Basic courses in the brotherhood school were associated with the church sciences. The school taught ecclesiastical regime, reading and interpretation of Scripture, understanding the liturgy, Orthodox tradition, teaching of the St. Fathers of the Church, life of saints and the Orthodox chant. For the purposes of brotherhood schools Lavrentij Zyzani published in 1596 in Vilnius the grammar of Slavic. A similar book was published in 1591 by Lviv brotherhood and in 1619 by Meletij Smotryc'kyj.

Brotherhood schools played important role in the life of the Orthodox Church in the Polish-Lithuanian Commonwealth. They had been preparing clergy, deacons and psalmists for the parish, especially during the collapse of the Orthodox hierarchy after the Union of Brest. A significant number of graduates were performing ancillary functions in the Orthodox churches. The best of them became teachers in other schools: brotherhood, court, parish and monastery. Schools released the greatest religious polemists and Orthodox activists: Stefan Zyzani (Kąkol), Jov Borec'kyj, Isaija Kopyns'kyj, Isaija Trofimowicz, Sylvester Kossov, Zaxariash Kopysten'skyj, Teofil Leontowicz. The activities of the Orthodox schools have contributed to improvement of religious awareness of Ruthenian population

In the last quarter of the 16th century the most important center of Orthodox intellectual life had been Ostroh Academy. The university was founded by Prince

\footnotetext{
33 K. Xarlampović, Zapadno-russkie..., p. 337.

34 S. Miropolsky, Ocherk..., p. 10.

35 K. Xarlampović, Zapadno-russkie..., p. 363-373.

36 I. 0. Flerov, O pravoslavnykh..., p. 114.
} 
Constantine Ostrogsky (1514-1608) in 1580, but full of its activity occurred after $1585^{37}$. The curriculum of the Ostroh Academy was similar to Western universities. The classical program of trivium (grammar, rhetoric, dialectic) and quadrivium (arithmetic, geometry, music and astronomy) was taught there. Also there were classes in Ruthenian, Latin and Greek languages ${ }^{38}$. The first rector of the Academy was Herasym Smotryc'kyj and then Sava Flaczyn and Cyril Lukaris, Greek from Crete. Among a large group of university lecturers were the Greeks: the Metropolitan Kizikos, Nicefor Parasios - emissary of the Patriarch of Constantinople, Emmanuel Achileos - religious polemist. Equally excellent lecturers were teachers of local origin: Jerzy Rohatyniec - author of Perestroha, Wasyl Maluszycki - disputatious writer and Jow Kniahicky. The Academy has maintained close contacts with monasteries in Derman, Dubno, Slutsk and later in Pochayiv. Graduates of the school were between others: religious disputatious, Zachariusz Kopysten'skyj, Hetman Petr Konaszewicz Sahaidachny, Vladika Gedeon Bałaban of Lviv and Meletij Smotryc'kyj of Polotsk. The Ostroh Academy will become a link between the Eastern Byzantine traditions and Western educational model. The Academy has contributed to the development of Ruthenian culture and literature, especially with publishing the Bible in 1581 in a Church Slavonic language.

Experiences of the Ostroh Academy have been used by the Metropolitan Petr Mohyla for setting up the Academy of Kiev. Metropolitan Petr Mohyla wanted to create modern school modeled on Jesuit colleges. Mohyla's actions triggered outrage among the Orthodox clergy, reluctant to adopt Latin patterns. The school has been accused of not truly reflecting the Orthodoxy. Monastic clergy did not understand the need of connecting western culture with the "Greek faith". Differently this problem was understood by Orthodox elite associated with Petr Mohyla, what led to merger of monastery school (mohylan) and Kiev brotherhood into one institution. Kiev school, in accordance with the model of other European schools, conducted classes in classical languages: Greek and Latin. School put emphasizes on teaching Polish language. School consisted of five lower grades: inferior (infima), grammar, syntaxis (syntaksyma), rhetoric, poetry and class of higher philosophy ${ }^{39}$. Lecturers at the College of Kiev were Sylvester Kossov, Isaija Trochimowicz Kozłowski, Ignat Aksienowicz Staruszycz, Sofroniusz Poczapski, Antoni Pacewski, Jazep Kananowicz Garbacki ${ }^{40}$. In 1632 Isaija Kozłowski, newcomer from Lviv and lecturer in philosophy, became the rector of Kiev school. The so-called "Ataneum Mohylańskie", gathering around Metropolitan outstanding humanists, has created a

T. Kempa, Konstanty Wasyl Ostrogski, wojewoda kijowski i marszałek ziemi wolyńskiej, Toruń 1997, pp. 102-103.

38 I. I. Micko, Ostrozhska sloviano-greko-latins'ka Akademia (1576-1636), Kiev 1990, p. 26.

39 K. Xarlampović., Zapadno-ruskie ..., pp. 362-362.

40 Makarii [S. Bulgakov], Istoriia Russkoi Tserkvi, Vol. 11, SanktPetersburg 1882, p. 13 foundation of the Orthodox academy, based on the principles of western science ${ }^{41}$.

Kiev College, later the Mohyla Academy, was to be modeled on Jesuit colleges. Romanization of education did not mean breaking with the Orthodox face of the university. Sylvester Kossov, rector of the university and polemicist, spoke in 1635 in defense of school's character in the work of Exegesis, to jest danie sprawy o szkołach kijowskich $i$ winnickich (Exegesis, it is about the matters of the Kiev and Vinnytsia schools). Kiev school, according to its defender, is not acceptable to Uniats, and is not conducive to the other dissenters. "Those who now study in Kiev and Vinnytsia schools, come from parents of the Greek religion, in that formed: educated in roman academies in Poland, Lithuania and in Empire. They study in Latin, by no means offend against ancient Greek religion. Belarusian Bishop Kossov rejoiced that "poor Ruthenia henceforth cannot stupid be called. In Poland, Latin is necessary. When poor fellow $\mathrm{Ru}-$ thenian finds oneself at the Sejm, (without) Latin does not make any step". Further Vladika Kossov pointed at the benefit of schools for the Orthodox Church. "Your churches hence with clergymen, pious and also competent, will be filled. Your cathedrals in eloquent preachers will flourish; your children, in their fathers' faith adamantine adorn with oratorical, philosophical, jurisdictional skills, at the general sejms, the courts of justice, yearly meetings (rokach), estates, with votes, discourses, councilors, will shine." ${ }^{42} \mathrm{Ki}$ ev-Mohyla Academy had become the most important Orthodox intellectual center, radiating across Eastern Europe. Special role had been played by its graduates in the life of the Russian Orthodox Church during the synodal period in the eighteenth century.

The role of schools in life of the Church and in shaping religious attitudes was understood by the creators of the Congregation of Pinsk. Among the provisions of July 3, 1791, reforming the Orthodox Church in the Republic can be found an article on the functioning of the Orthodox education. Education was extended to the children of clergy, nobility and townspeople "and even peasant children, according to the national laws". "Bachelors may be grandparents, who can read and write in Polish and in Ruthenian, but if they were very engaged in church service, then other schoolteachers than grandparents have to be maintained. The obligation to organize and maintain parish schools had parsons and monastery superiors ${ }^{43}$. On the $9^{\text {th }}$ of December 1791 Supreme Consistory appointed by the Congregation of Pinsk ordered to monastery superiors to conduct education of tenets of Orthodox faith among the faithful and

\footnotetext{
41 A. Jabłonowski, Akademia Kijowsko-Mohylańska, Cracow 1899-1900, pp. 86-89.

42 Makarii [S. Bulgakov], Istoriia Russkoi Tserkvi, Vol. 11, p. 422; A. Mironowicz, Sylwester Kossow, biskup białoruski, metropolita kijowski, Białystok 1999, pp. 9-12.

43 E. Sakowicz, Kościół prawosławny w Polsce w epoce Sejmu Wielkiego 1788-1792, Warsaw 1935, pp. 205-206; A. Mironowicz, Cerkiew prawosławna na terenie Wielkiego Księstwa Litewskiego w latach 1772-1795, in M. Biskup (Ed.), Ziemie Północne Rzeczypospolitej Polsko - Litewskiej $w$ dobie rozbiorowej 1772-1815, Warsaw - Toruń 1996, pp. 81-94; Idem, Ihumen Sawa Palmowski, Białystok 2001, pp. 33-62.
} 
organizing parish schools. Orthodox authorities had begun preparing textbooks to teach religion and auxiliary materials. Introduced school reforms had contributed to the development of education among Orthodox community. This process had not lasted long. The outbreak of Polish-Moscow war and the Second and the third Partition of the Polish-Lithuanian Commonwealth cancelled provisions of the Congregation of Pinsk and ended the reform of education.

During partitions Orthodox education at different levels developed under the influence of the Russian Orthodox Church. The most popular were the "gramot" schools. The staff of these schools comprised folk schools" graduates and retired soldiers. Only in 1891 rules for the functioning of the "gramot" schools were set out and they were renamed for elementary schools. Such schools were to be established in rural areas and cities. Condition for their establishing was notification through the parson of school activities to the authorities of education. Schools were mostly organized by the Orthodox clergy themselves.

In contrast to the folk schools ("gramot"), greater importance for education had one- and two-grade educational units. In schools of that type there was higher proportional share of religion classes in relation to other subjects, another composition of the teaching staff and substantive supervision. In practice, especially in one-grade schools, teachers were still children of peasants and retired military. One- or two-grades schools introduced such additional activities as: gymnastics, hygiene, botany, horticulture, bee-keeping, herbalism, arithmetic, singing, playing the violin or drill ${ }^{44}$. The difference between the two-grade schools and one-grade schools lay in the duration of teaching cycle and its quality. In two-grade schools (four years), $37.5 \%$ were religious subjects and $62.5 \%$ secular. Geography was singled out from the history and merged with the nature. In curriculum there were also vocational courses like drawing, craft, gymnastics and agriculture. Vocational courses were supplemented by the general subjects: pedagogy, arithmetic, didactics, psychology, Ruthenian language, history and teaching methodology. Basic canon of religious subjects was still obligatory: catechism, theology, order of services, Orthodox chant, Orthodox Church history, etc. Orthodox parish schools of all levels, including the teaching seminar, were subjected to the supervision of the clergy. Development of this type of education was in the Orthodox authorities' interest. Schools of this type served the needs of Orthodox Church and educated young people in a religious spirit.

Clergy received their education in a number of theological seminaries i.e. in Annopol, Khelm, Polotsk, Vilnius and Zhyrovitse. In 1836 the Annopol seminar near Ostroh moved to Kremenets. Based on the seminar in Kremenets, district and parish schools were created. In 1838 both units

\footnotetext{
44 See I. Matus, W Puchłach, Stawku, Trześciance. Z dziejów oświaty ludu białoruskiego na Podlasiu, Białystok 2000.
}

numbered 437 students $^{45}$. In 1845 the seminary in Zhyrovitse was closed down and seminarians were moved to Vilnius ${ }^{46}$. Theological seminars were structured into 6 grades, based on clerical schools (dukhovnyje uchylishcha). In the period 1828-1872 there were clerical schools in Hrodna, Kobryn, Zhyrovitse and Vilnius. In 1872 the clerical school in Kobryn and Hrodna were closed down and their students transferred to Polotsk and Vilnius. After 1875 in Khelm Land, seminary in Khelm and clerical school in Pochayiv were established. At the beginning of World War I, a seminar was evacuated from Khelm to Moscow, and in 1918 had been placed in Kremenets. Orthodox clergy could obtain full theological studies from the Academy of Theology in St. Petersburg, Kiev, Kazan and Moscow.

Already in 1919, after regaining independence in the Second Polish Republic, Orthodox Church hierarchy had sought to resume the work of the seminar in Vilnius and Krements. At that time, in Krements operated two schools: male and female. Both theological schools by decision of education authorities had been resolved in 1921. Orthodox authorities transferred the Kremenets schools to Derman. In Derman male clerical school functioned until 1926 and female until 1930. Both schools operated on the basis of authorization of Volyn Superintendent and had the status of private schools. Schools were held by local clergy. Following the transfer of both of Keremenets schools to Derman, Orthodox authorities had launched theological seminar in Kremenets. In this situation, since 1921 on lands of the Second Republic operated two seminaries in Vilnius and Kremenets. Seminaries were in difficult financial position and required structural and curriculum reforms. Powers of clerical schools required legal regulation. In addition, Polish authorities claimed the allegations against teaching staff of the seminaries about their links with the national movement. Authorities pointed to the Belarusian influences in the Vilnius seminary and Ukrainian influences in the Kremenets seminary. The building of the Vilnius seminary also housed Belarusian gymnasium and rector of the seminary was well-known Belarusian activist Wiaczesłau Bahdanowicz. In turn, in Kremenets there were strong influences of Ukrainian national organizations. Russians and Ukrainians made up teaching staff. Under the pressure of the state, in 1922 synod of bishops appointed a new rector of the seminary in Vilnius and removed Belarusian gymnasium from seminary buildings ${ }^{47}$.

On the Ministry of Religious Affairs and Public Enlightenment initiative reforms in Orthodox education had been made. Theological seminaries had been converted into ten-grade schools, having the authorizations of high schools. New seminaries integrated the former seminary and secular middle school. The seminary training ended with matura (secondary school certificate). Education

\footnotetext{
45 Tserkva i narid, No. 11, Kremenets 1936, pp.455-458.

46 Litovskie Jeparkhialnye Vedomosti, No. 18, Vilnius 1866, pp. 703-717.

47 M. Papierzyńska-Turek, Między tradycją a rzeczywistością. Państwo wobec prawosławia 1918-1939, Warsaw 1989, pp. 280-281.
} 
authorities had had an impact on the management of the seminaries, so that from the theological curriculum polemical to other faiths elements were removed. Authorities' rebukes focused primarily on programs of such subjects as history of Orthodox Church, comparative theology and pastoral work ${ }^{48}$. State authorities had tried, if not to eliminate the Kremenets and Vilnius seminaries, to considerably limit their activities. Eventually, after the education reform, since October 1924 Vilnius seminar had been divided into eight-grade gymnasium and two-year theological college. The theological collage had status of private school, but was subsidized by the Ministry. In October 1925, the Ministry transformed Vilnius and Kremenets seminaries into ninegrade public schools. Seminaries were to be financed by the government and were directly subordinated to the Metropolitan. Apart from theological subjects all lectures were held in Polish. Seminary graduates were to be admitted to College of Orthodox Theology the University of Warsaw. In 1932, in connection with the Jędrzejewski's school reform new rules had been set for the functioning of cleric education. Candidates for the priesthood after finishing six grades of elementary school and 4-year middle school had to complete 2-year theological high school. The ministerial reforms triggered disorganization of Orthodox seminaries. After numerous controversies, finally in 1935, the objectives of cleric education reform were specified. They were assuming gradual elimination of both of seminaries and opening in their place in the academic year 1938/39 the three-year theological high school in Warsaw. Authorities were supposed to have a decisive impact on the functioning of the theological school, that is, the role of the Metropolitan was greatly reduced. Presidential Decree of 1938 set out the basis for a new legal system of Orthodox clergy education ${ }^{49}$. Outbreak of World War II meant that they would remain only in the sphere of legal and organizational preparations.

In addition to theological seminaries in Vilnius and Kremenets, theological school at Pochayiv Lavra for children of clergy and the school for Orthodox choir conductors in monasteries in Jabłeczna and Kremenets were founded by the Metropolitan Dionizy Valedynsky (19231939, 1940-1948). In 1923 Orthodox authorities have taken an attempt to create private theological school in the village of Witczówka in Polesia. This project was not implemented because of the strong opposition from provincial authorities, who feared so that the school would not become "the seedbed of the Eastern culture" 50 .

In the interwar period special role in the process of clergy's education in the Orthodox Church played College of Orthodox Theology at the University of Warsaw. The basis for its establishment was a project of creating university education for clerical personnel, submitted to the Ministry of Religious Affairs and Public Enlightenment in 1921 by the Metropolitan George Jaroshevsky. Finally, in 1924, thanks to the efforts of the Metropolitan Dionizy Valedyn-

\footnotetext{
48 A. Malesza, Szkolnictwo in L. Adamczuk and A. Mironowicza (Eds.), Kościół prawosławny w Polsce. Dawniej i dziś, Warsaw 1993, pp. 114-115.

49 M. Papierzyńska-Turek, Między tradycją a rzeczywistością, pp. 286-287.

50 Ibid., pp. 288-289.
}

sky, the Senate passed a resolution on creation the College of Orthodox Theology at University of Warsaw. The college commenced operations on February 8, 1925. The head of the College became Metropolitan Dionizy Valedynsky and his deputy Professor Ivan Ohijenko. Academic staff consisted of outstanding specialists in history, theology and dogmatics of the Orthodox Church. Lecturers at the University of Warsaw were: Rev Metropolitan Professor Dionizy Valedynsky, Professor Bazyli Bidnow, Rev Archimandrite Professor Grigol Peradze, Professor Mikołaj Arseniew, Rev Archimandrite Professor Hilarion Basdekas, Professor Michał Zyzykin, Bishop Professor Aleksander Zotos, Professor Ivan Ohijenko, Professor Aleksander Łotocki, Professor Sergiusz Kisiel-Kisielewski and lecturers Aleksander Łapicki (PhD) and Włodzimierz Kułakow ${ }^{51}$. Most of the scientists have graduated Russian theological academies in Kazan (D. Valedynsky), Kiev (B. Bidnov and A. Łotocky), Moscow (W. Kułakov) and St. Petersburg (H. Basdekas). The assembly of such outstanding lecturers was possible thanks to the support of other Orthodox churches staff. Romanian Orthodox Church delegated to work in the College of Orthodox Theology Professor Sergiusz Kisiel-Kisielewski, an eminent Hebraist and expert in the Old Testament and $\mathrm{PhD}$ Justyn Moisescu, later Metropolitan of Moldova and Patriarch of Romania. Bishop Aleksander Zotosa and Archimandrite Hilarion Basdekas were associated with the Constantinopolitan Church. The College, through the research staff, was adopting the good traditions of the Russian theological academies and theological schools of Romania and Western Europe. Archimandrite Grigol Peradze was a graduate of the Faculty of Protestant Theology in Berlin and Archimandrite Hilarion Basdekas St. Petersburg Theological Academy and the University of Oxford $^{52}$. Preparation of College lecturers influenced specializations and methods of research and the nature of education. Until 1939 College had educated an excellent staff of clergy and academics. Graduates of the college were, among others, George Shretter, the later Metropolitan Timothy of Warsaw, Borys Borysiewicz - the later Archbishop Cyprian of the United States of America Orthodox Church, Mitrofan Gutowski, the later bishop of the Russian Orthodox Church. These graduates show a broader educational role of Warsaw University. Graduates of the College of Orthodox Theology strengthened resources of many Orthodox churches. In the period 1928-1939 249 graduates were granted master's degree in the Orthodox theology. Employees of the study also brought important contribution to research in the field of theology and church history. The work of professors Basdekas, Zyzykin, Ohijenko, Bidnov and Łotocky permanently affiliated with the biggest achievements of scientific staff at the University of Warsaw. Their scientific achievements were known at home and abroad. Scientific journal "Elpis" enjoyed a widespread recognition among historians of the Church and theologians. Alumnus

M. Linczewski, Studium Teologii Prawosławnej na Uniwersytecie Warszawski w latach 1925-1939, Warsaw 1992, pp. 42-65

52 Ibid., pp. 38-41. 
and employees of the College have contributed to the rebirth of theological education in post-war Poland. College's worker Dr. Aleksander Łapinski later became a professor of Orthodox Section of Christian Theological Academy in Warsaw.

During the World War II, in the period 1942-1944, Orthodox seminary in Warsaw was established, and in the period1943-1944 seminary in Khelm. The purpose of those both schools of theology was to prepare personnel for pastoral work. Restoration of decimated clerical staff was a major task in the postwar period. Metropolitan Dionizy attempted to reactivate the College of Orthodox Theology at the University of Warsaw. Refusal of the Ministry of Public Administration to establish a study led to Metropolitan decision of setting up on January 1, 1948, the Private College of Orthodox Theology at the Orthodox Metropolitan Cathedral in Warsaw. After the removal of Metropolitan Dionizy from the position, Archbishop Timothy, Chairman of the Interim Governing Council of the The Orthodox Autocephalous Church of Poland, took the initiative to invoke a seminary. Thanks to his efforts, on the $20^{\text {th }}$ of March 1950 Orthodox School of Theology in Warsaw opened up. Already in the 1951/1952 academic year the school has been transformed by the Metropolitan Makarij into four-year Orthodox Seminary. In 1970, Metropolitan Bazyli moved the seminar to the Monastery in Jabłeczna. In this form seminar operated until September 1, 1975. Since that academic year, the two-year Higher Orthodox Seminary started to operate. Finally, by decision of the Council of Bishops of the The Oththodox Autocephalous Church of Poland, seminary in Jabłeczna was resolved in 1992.

Since 1970 in seminary buildings in Warsaw, branch of high school was functioning. School has been transformed into a seminary, which obtained the status of secondary theological school. Graduates of the seminar received matura and good theological preparation for the pastoral work. Initially, the seminar was financed from the budget of the metropolis, but since 1984 it obtained financial independence. In 1992, arose the project of training seminarians at a higher level. The seminary in Warsaw, after changes in curriculum and staffing, has obtained the status of the Higher Orthodox Theological Seminary. Since 1998, the curriculum in Orthodox Theological Seminary ended to a bachelor degree, which is recognized by the state's educational authorities ${ }^{53}$.

\footnotetext{
53 „Prawosławne Seminarium Duchowne. 50 lat”. ,Warsaw 2001, pp. 9-18.
}

A special role in the preparation of cleric staff has the Orthodox Section of the Christian Academy of Theology. Its formation was a result of efforts of Metropolitan Makary and decision of the Ministry of Higher Education from September 3, 1957. Organizational changes in the Christian Academy of Theology led to creation under the Orthodox Theology Section of the three cathedrals: Exegesis of Sacred Scripture of the Old Testament, Petrology and the History of the Orthodox Church. In 1958 another two cathedrals were set up: Exegesis of the New Testament Scripture and Dogmatic and Morality Theology. Students were recruited mainly from the seminary. Staff of the Orthodox Section of the Christian Academy of Theology continued traditions of College of Orthodox Theology at the University of Warsaw. Rich scientific and educational achievements of workers of Christian Theological Academy resulted that university, as the only Orthodox scientific body in this part of Europe, has the power to award doctorate degree and senior doctorate in the field of theology.

In recent years there has been a new initiative of Orthodox theology education at university level. As a result of efforts of Metropolitan Sawa (Hrycuniak) of Warsaw, in 1999 the Department of Orthodox Theology at the University of Białystok was appointed. Department brings together eminent specialists in the field of dogmatics, theology and history of the Orthodox Church. Carried out by Department's staff postgraduate study gained popularity among the graduates of other faculties. Another step in the development of theological studies at the academic level is to be establishment of the Faculty of Theology at the University of Białystok, consisting of two specializations: Orthodox and Roman Catholic. Project of theological studies at the University of Białystok is unique initiative in the universal Church ${ }^{54}$.

Worth mentioning are another two educational initiatives: Iconographic College in Bielsk Podlaski and Orthodox Psalmists College in Hajnowka. Iconographic College was established in 1991 in order to prepare professional staff for creation and preservation of sacred Orthodox art. The study received status of private artistic school and remains under the supervision of the Ministry of Culture and Arts. Orthodox Psalmists College was founded in 1996. The task of this private school is preparing psalmists and conductors to meet the needs of Orthodox Church ${ }^{55}$.

„ЕАПІ . Czasopismo Teologiczne Katedry Teologii Prawosławnej Uniwersytetu w Białymstoku”, Vol. I (XII), No. 1 (14), Białystok 1999, pp. 11-21; Vol. III (XIV), No. 4 (17), Białystok 2001, pp. 37-38.

55 „Kalendarz Warszawskiej Metropolii Prawosławnej” for 2002, Warsaw 2001, pp. 173-181. 


\section{Bibliography}

Bieńkowski L., Organizacja Kościoła wschodniego w Polsce XVI -XVIII w., [in:] Kościót w Polsce, ed. J. Kłoczowski, part. II, Cracow 1969.

Blazejowskyj D., Hierarchy of the Kyivan Church (861-1990), Romae 1990.

Xarlampović K., Zapadno-russkie pravoslavnye shkoly XVI i nachala XVII w., Kazan 1898.

Chodynicki K., Kościół prawosławny a Rzeczpospolita Polska, 1370-1632, Warsaw 1934.

Chrześcijaństwo w Polsce. Zarys przemian 966-1975, ed. J. Kłoczowski, Lublin 1992.

Deruga A., Piotr Wielki a unia kościelna 1700-1711, Wilno 1936.

Dzięgielewski J., O tolerancje dla zdominowanych. Polityka wyznaniowa Rzeczypospolitej w latach panowania Władysława IV, Warsaw 1986.

Fijałek J., Biskupstwa greckie na ziemiach ruskich od połowy XIV wieku na podstawie źródet greckich, "Kwartalnik Historyczny", vol. XI, 1897.

Fijałek J., Średniowieczne biskupstwa Kościoła Wschodniego na Rusi i Litwie, "Kwartalnik Historyczny”, vol. X, 1896.

Gołubinsky E., Istoria Russkoi Tserkvi, vol. I-II, Moscow 19001902.

Gudziak B., Crisis and Reform. The Kyivan Metropolitanate, the Patriarchate of Constantinople, and the Genesis of the Union of Brest, Cambridge. Mass. 1998.

Jabłonowski A., Akademia Kijowsko-Mohylańska, Cracow 18991900.

Krypjakevych I. P., Z istorii halytskoho shkilnytstva XVI-XIII st., ,Ridna szkoła”, Lwiw 1933, No. 2;

Kupraneć O. F., Pravosłavna Tserkva w mizhvojennij Polshchi 1918-1939, Rym 1974.

Linczewski M., Studium Teologii Prawosławnej na Uniwersytecie Warszawski w latach 1925-1939, Warsaw 1992.

Makarii, Istoria Russkoi Tserkvi, kn. 3, part 1, Moscow 1995.

Malesza A., Szkolnictwo in L. Adamczuk and A. Mironowicza (Eds.), Kościót prawosławny w Polsce. Dawniej i dziś, Warsaw 1993

Martos A., Belaruś w istoricheskoj, gosudarstvienoj i tserkovnoj zhiźni, Buenos-Aires 1966.

Matus I., W Puchłach, Stawku, Trześciance. Z dziejów oświaty ludu białoruskiego na Podlasiu, Białystok 2000.

Medynsky E. N., Bratskie shkoły Ukrainy i Bielorussii w XVI-XVII w., Moscow 1954.

Mironowicz A., Bractwa cerkiewne w Rzeczypospolitej, Białystok 2003.

Mironowicz A., Charitable Work of the Orthodox Church in the Polish-Lithuanian Commonwealth $\left(16^{\text {th }}-18^{\text {th }} c\right.$ c.), "Acta Poloniae Historica", vol. LXXXVII, 2003.

Mironowicz A., Ihumen Sawa Palmowski, Białystok 2001.

Mironowicz A., Józef Bobrykowicz, biskup białoruski, Białystok 2003.
Mironowicz A., Kościół prawosławny na ziemiach polskich w XIX i XX wieku, Białystok 2005.

Mironowicz A., Kościót prawosławny w dawnej Rzeczypospolitej, Białystok 2001.

Mironowicz A., Kościół prawosławny w państwie Piastów i Jagiellonów, Białystok 2003.

Mironowicz A., Kościół prawosławny w Polsce, Białystok 2006.

Mironowicz A., Szkolnictwo prawosławne na ziemiach białoruskich w XVI-XVIII wieku, "Białoruskie Zeszyty Historyczne", No. 2, Białystok 1994.

Mironowicz A., Prawosławne szkolnictwo teologiczne na terenie Rzeczypospolitej, [w:] Od Kijowa do Rzymu. Z dziejów stosunków Rzeczypospolitej ze Stolica Apostolską i Ukraina, pod red. M. R. Drozdowskiego, Białystok 2012, s. 863-880.

Mironowicz A., Sylwester Kossow, władyka białoruski, metropolita kijowski, Białystok 1999.

Mironowicz A., Teodozy Wasilewicz, archimandryta słucki, biskup białoruski, Białystok 1997.

Miropolsky S., Ocherk istorii tserkovno-prikhodskoi shkoly od piervogo ieia vozniknienia na Rusi do nastoiashchego vriemieni, 3rd ed., Sankt-Peterburg 1985.

Papierzyńska-Turek M., Między tradycją a rzeczywistością. Państwo wobec prawosławia 1918-1939, Warsaw 1989.

Pawluczuk U., Życie monastyczne w II Rzeczypospolitej, Białystok 2006.

Pavlovsky J., Prikhodskie shkoly v staroi Malorussii i prichiny ich unichtozhenia, Kiev 1904;

Pelesz J., Geschichte der Union der ruthenischen Kirche mit Rom von den ältesten Zeiten bis auf die Gegenwart, vol. II, Würzburg-Wien 1881.

Podskalsky G., Christentum und Theologische Literatur in der Kiever Rus' (988-1237), München 1982.

Poppe A., Państwo i Kościół na Rusi w XI wieku, Warsaw 1968.

Prawosławne oficyny wydawnicze w Rzeczypospolitej, pod red. A. Mironowicza i U. Pawluczuk, Białystok 2004.

Prawosławne Seminarium Duchowne. 50 lat, Warsaw 2001.

Sakowicz E., Kościót prawosławny w Polsce w epoce Sejmu Wielkiego 1788-1792, Warsaw 1935.

Savich A., Zapadno-russkie uniatskie shkoly XVI-XVII w., Trudy Bieloruskogo Gosudarstviennogo Univiersitieta w Minskie", Minsk 1922, No. 2-3.

Senyk S., A History of the Church in Ukraine, Rome 1993.

Sysyn F., Between Poland and the Ukraine. The Dilemma of Adam Kysil 1600-1653, Cambridge Mass. 1985.

Szkolnictwo prawosławne w Rzeczypospolitej, pod red. A. Mironowicza i U. Pawluczuk, Białystok 2002.

Wańczura A., Szkolnictwo w Starej Rusi, Lwów 1932

Woliński J., Polska i Kościót prawosławny. Zarys historyczny, Lwów 1936.

Życie monastyczne w Rzeczypospolitej, pod red. A. Mironowicza i U. Pawluczuk, Białystok 2001. 